\title{
Ocena satysfakcji rodziców z leczenia ludz- kim rekombinowanym hormonem wzrostu dzieci z somatotropinową niedoczynnością przysadki
}

\author{
Assessment of parents' satisfaction with treatment with human recom- \\ binant growth hormone in children with somatotropin hypopituita- \\ rism \\ LECH GRZELAK ${ }^{1,2}$, ANNA WIŚNIEWSKA ${ }^{3}$, ROBERT ŚLUSARZ1 \\ ${ }^{1}$ Instytut Nauk o Zdrowiu, Państwowa Uczelnia Zawodowa we Włocławku \\ ${ }^{2}$ Koordynator Oddziału Neurochirurgii Specjalistycznego Szpitala Miejskiego w Toruniu \\ 3. Oddział Pediatrii, Endokrynologii, Diabetologii i Neurologii Dziecięcej w Szpitalu Dziecię- \\ cym w Toruniu
}

DOI: http://dx.doi.org/10.21784/IwP.2020.021

ISSN: 2451-1846

\section{Streszczenie}

Wstęp. Niskorosłość jest określeniem wzrostu dziecka poniżej dwóch odchyleń standardowych od norm przyjętych dla płci i wieku. W Polsce refundacji podlega leczenie rekombinowanym hormonem wzrostu somatotropinowej niedoczynności przysadki w ramach programów lekowych Narodowego Funduszu Zdrowia. Podawanie hormonu wzrostu w postaci codziennych iniekcji jest uciążliwe i wymaga zaangażowania całej rodziny w proces leczenia. Wielokierunkowe działanie GH poprawia jakość życia małych pacjentów.

Cel. Celem pracy jest analiza satysfakcji rodziców z leczenia hormonem wzrostu dzieci z somatotropinowa niedoczynnością przysadki. 
Materiał i metody. W badaniu wzięło udział 69 rodziców dzieci z somatotropinową niedoczynnością przysadki leczonych hormonem wzrostu na oddziale Pediatrii, Endokrynologii, Diabetologii i Neurologii Dziecięcej w Szpitalu Dziecięcym w Toruniu. Do badań wykorzystano ankietę własną oraz standaryzowany kwestionariusz KIDSCREEN-52 wersja dla rodziców.

Wyniki. Rodzice dzieci z somatotropinową niedoczynnością przysadki są usatysfakcjonowani z leczenia rekombinowanym hormonem wzrostu i oceniają kuracje pozytywnie. W trakcie terapii hormonem wzrostu wysoko oceniają jakoś życia swoich dzieci. Istnieje zależność pomiędzy oceną przez rodziców terapii hormonem wzrostu a zmianą jakości życia ich dzieci.

Wnioski. Satysfakcja z leczenia rekombinowanym hormonem wzrostu jest zależna od czasu trwania kuracji, osiągniętych rezultatów wzrostowych oraz wieku dziecka.

Słowa kluczowe: niskorosłość; terapia hormonem wzrostu; satysfakcja rodziców; somatotropinowa niedoczynność przysadki.

\section{Summary}

Introduction. Short stature is a term for a child's height below two standard deviations from the norms adopted for sex and age. In Poland, treatment with recombinant growth hormone of somatotropin hypopituitarism is reimbursed under the National Health Fund drug programs. Administration of growth hormone in the form of daily injections is cumbersome and requires the involvement of the whole family in the treatment process. The multidirectional action of GH improves the quality of life of small patients.

Aim. The aim of the study is to analyze parents' satisfaction with growth hormone treatment in children with somatotropin hypopituitarism.

Materiał and methods. The study involved 69 parents of children with somatotropin hypopituitarism treated with growth hormone at the Department of Pediatrics, Endocrinology, Diabetology and Pediatric Neurology at the Children"s Hospital in Torun. The research used the own questionnaire and KIDSCREEN questionnaire for parents.

Results. Parents of children with somatotropin hypopituitarism are satisfied with the treatment with recombinant growth hormone and evaluate the 
treatment positively. During growth hormone therapy, they highly estimate the quality of their children's lives. There is a correlation between parents' assessment of growth hormone therapy and the change in their children's quality of life.

Conclusions. Satisfaction with treatment recombinant growth hormone depends on the duration of treatment, achieved growth results and the child's age.

Keywords: short stature; somatotropin hypopituitarism; parents satisfaction with growth hormone therapy.

\section{Wstęp}

Wzrastanie jest zależne od czynników genetycznych, metabolicznych a także hormonalnych. Wzrost jest uwarunkowany stanem zdrowia, dostarczeniem składników odżywczych i prawidłowo działającym układem nerwowym i hormonalnym. Istnieją choroby przewlekłe, które spowolniają wzrastanie u dziecka. Zwolnione tępo wzrostu może wyprzedzać o miesiące i lata wystąpienie chorób np.: choroby trzewnej. Niski wzrost jest jedną z najczęstszych z przyczyn kierowania dziecka do endokrynologa, ale znikomy procent wymaga leczenia hormonalnego. Oceniając dziecko niskorosłe należy brać pod uwagę pozycje centylową wzrostu dziecka. Pozycję centylową określa się na podstawie siatek centylowych opracowanych przez Zakład Rozwoju Dzieci i Młodzieży Instytutu Matki i Dziecka w Warszawie. Postęp w dziedzinie genetyki umożliwia postawienie dokładnej diagnozy ocenę rokowania i możliwości leczenia. Niskorosłość to określenie stanu wzrostu dziecka poniżej 3 centyla na siatce centylowej, poniżej 2 odchyleń standardowych(-2SD) od normy dla płci i wieku. Dzieci z tak określonym niedoborem nie wykazują cech choroby. Niski wzrost dotyczy 3\% populacji. W Polsce około 200000 dzieci ma postawioną diagnozę zaburzeń wzrastania z czego 1,5\% powodują zaburzenia w uwalnianiu hormonu wzrostu $[1,2,3,4,5]$. 
Hormon wzrostu (growth hormone, GH) nazywany somatotropiną jest produkowany przez komórki przedniego płata przysadki mózgowej. Synteza GH następuje w komórkach somatotropowych, które znajdują się lateralnie w przednim płacie przysadki. Rola hormonu wzrostu polega na stymulacji procesów wzrastania. Hormon pełni różne funkcje w organizmie i zależy w jakim okresie rozwoju jest organizm. Pobudza wzrost i podział komórek, chrząstek, wpływa na dojrzewanie płciowe, gospodarkę lipidową, węglowodanową, białkową, wodnoelektrolitową. Ma też wpływ na układ mięśniowy i krążenia. Hormon wpływając na układ kostny działa bezpośrednio na pobudzenie wzrostu kości długich, zapewniając prawidłową mineralizacje kości $[6,7,8,2]$.

Somatotropinowa niedoczynność przysadki (SNP) powstaje na skutek upośledzonego wydzielania hormonu wzrostu przez komórki somatotropowe przysadki w okresie rozwojowym, powodując upośledzenie tempa wzrastania. (SNP) może występować jako izolowane schorzenie a przy braku wydzielaniem innych hormonów przysadki występuje wielohormonalna niedoczynności przysadki (WNP). Przyczyny somatotropinowej niedoczynności przysadki mogą być nabyte i wrodzone. Bardzo często SNP spowodowana jest wadami rozwoju okolicy podwzgórzowo-przysadkowej i uszkodzeniami w okresie ciąży i porodu. Występowanie SNP ocenia się 1:4000 - 1:10 000 żywych urodzeń. Większość przypadków somatotropinowej niedoczynności przysadki ma podłoże idiopatyczne $[9,10,7,2,11]$.

Niedobór hormonu wzrostu to zaburzenie, które nie powoduje typowych objawów somatycznych. Początkowo rodzice są zaniepokojeni wzrostem swojego dziecka, które jest znacznie mniejsze niż dzieci w jego wieku. Dzieci „niskie” są wyszydzane, wyśmiewane przez kolegów. Często traktowane jako młodsze, wyklucza się je z zabawy, przyjaźni. U dzieci z niskorosłością dominują zachowania wycofania, występuje u nich lękliwość, często zburzenia koncentracji. Niski wzrost 
potęguje izolację społeczną, niską samoocenę, brak umiejętności społecznych. Rodzice zgłaszają, że ich dziecko spotyka się z traktowaniem typu: zaczepki, drażnienie, fizyczne znęcanie. Niskorosłość dziecka trudno zaakceptować rodzicom, często zaburzone zostają relacje pomiędzy członkami rodziny. Dysfunkcja życia w grupie rówieśniczej w skrajnych przypadkach może doprowadzić do prób samobójczych. To jak niskorosłość jest odbierana przez dziecko zależy również od tego jak rodzice akceptują niedobór wzrostu. Dziecko na tej podstawie buduje swoje poczucie wartości. Istnieje bowiem przekonanie, że wysocy ludzie osiągają bardziej prestiżowy zawód $[1,12,13,14,15,16]$.

Somatotropinowa niedoczynność przysadki jest podstawowym wskazaniem do leczenia hormonem wzrostu. W Polsce do refundowanej terapii ludzkim rekombinowanym hormonem wzrostu kwalifikuje Zespól Koordynacyjny ds. Stosowania Hormonu Wzrostu. Programy zdrowotne- lekowe Narodowego Funduszu Zdrowia określają kryteria włączenia i wyłączenia z leczenia hormonem wzrostu. Leczenie jest ściśle określone i trwa do czasu podjęcia przez Zespół ds. Stosowania Hormonu Wzrostu bądź lekarza prowadzącego decyzji o wyłączenia z programu zgodnie z kryteriami $[6,17,18,5]$.

Podjęcie decyzji o leczeniu hormonem wzrostu wymaga zaangażowania całej rodziny w program terapeutyczny. Konieczne, okresowe wizyty w szpitalu. Pobieranie krwi do badań kontrolnych, wymagają przygotowania psychicznego dziecka. Dziecko zakwalifikowane do leczenia hormonem wzrostu musi codziennie otrzymywać podskórne iniekcje. Rodzic przechodzi szkolenie jak należy poprawnie wykonać wstrzykniecie i przechowywać hormon wzrostu. Na początku leczenia jest to bardzo stresujące, szczególnie dla małych dzieci. Pobyt w szpitalu w celu wykonania badań kontrolnych jest często przyczyną płaczu i stresu dla dziecka. Hormon wzrostu musi być zawsze przechowywany w lodówce także podczas urlopu, podróży czy innych sytuacjach życiowych. 


\section{Cel}

W pracy podjęto próbę analizy satysfakcji rodziców z leczenia ludzkim rekombinowanym hormonem wzrostu dzieci z somatotropinową niedoczynnością przysadki. Postawiono sobie pytania jak rodzice oceniają leczenie. Czy tylko poprawą jakości życia leczonych dzieci? Czy istnieje zależność między ich oceną a oceną jakości życia leczonego dziecka? Jak wreszcie długotrwałość leczenia i osiągnięty rezultat wzrostu wpływa na satysfakcję rodziców z leczenia ich dzieci.

\section{Materiał i metody}

Badania prowadzone były wśród rodziców dzieci z somatotropinową niedoczynnością przysadki leczonych ludzkim rekombinowanym hormonem wzrostu w Wojewódzkim Szpitalu Zespolonym im. Rydygiera w Toruniu na oddziale Pediatrii, Endokrynologii, Diabetologii i Neurologii Dziecięcej, w terminie od 01.12.2019 do 01.02.2020r. Na badania uzyskano zgodę Komisji Bioetycznej przy Wydziale Nauk o Zdrowiu Państwowej Uczelni Zawodowej we Włocławku.

Spośród 69 ankietowanych rodziców, 77\%(53) stanowiły kobiety, 23\%(16) mężczyźni. Grupa ankietowanych została zróżnicowana pod względem wieku rodziców. 57\%(39) stanowili rodzice w wieku od 25 do 35 lat, natomiast 41\%(28) respondentów miało powyżej 35 lat, natomiast 3\%(2) stanowili ankietowani rodzice przed 25 rokiem życia.

Wśród dzieci leczonych rekombinowanym hormonem wzrostu 70\%(48) stanowili chłopcy, natomiast 30\%(21) dziewczynki.

W przeprowadzonych badaniach zastosowano technikę badawczą metodą sondażu diagnostycznego. Narzędziem badawczym były: metryczka oraz kwestionariusze ankiet, które służyły do realizacji wybranej techniki badań. Do badań wykorzystano również standaryzowany kwestionariusz zdrowotny dla dzieci i młodzieży KIDSCREEN-52 w wersji dla rodziców, który służy do badania 10 wymiarów jakości życia: samopoczucie fizyczne (W1), samopoczucie 
psychiczne (W2), nastroje i emocje (W3), obraz własnej osoby (W4), niezależność (W5), relacje z rodzicami i dom (W6), zasoby finansowe (W7), wsparcie społeczne, koledzy (W8), środowisko szkolne (W9) oraz akceptacja społeczna (W10). Przy pomiarze danego obszaru/wskaźnika za najlepszy wynik przyjmuje się 100, natomiast im niższy wynik na skali tym gorsza jakość życia w danym obszarze/wskaźniku.

Do oceny statystycznej wykorzystano test Shapiro-Wilka, nieparametrycznego testu U Manna-Whitney'a oraz współczynnika korelacji rang Spearmana (Rs). Założono poziom istotności $\alpha=0,05$. Za istotne statystycznie uznawano wyniki, gdy wyliczone prawdopodobieństwo testowe $\mathrm{p}$ spełniało nierówność $\mathrm{p}<0,05$. Do analizy statystycznej wykorzystany został program Statistica 10.0 (StatSoft Inc., 2011).

\section{Wyniki}

W przebiegu przeprowadzonych badań stwierdzono w 77\% przypadkach zgodność efektów leczenia z oczekiwaniami rodziców jako bardzo dużą, w 17\% przypadków średnią a tylko 5\% jako „trochę” lub „wcale”. Korespondowało to z spostrzeżeniem przez rodziców wzrostu samooceny dziecka. $46 \%$ rodziców uznało, że leczenie bardzo przyczyniło się do wzrostu samooceny dziecka, $28 \%$ zadeklarowało, że „średnio", 20\%, że "trochę”, natomiast 6\% udzieliło odpowiedzi „wcale”. Może to być powiązane z poprawą spostrzegania dziecka w grupie rówieśniczej. Badania wykazały, że $41 \%$ respondentów zauważyło pozytywny wpływ leczenia na postrzeganie dziecka w grupie rówieśniczej, 33\% zadeklarowało średni wpływ, 16\% udzieliło odpowiedzi "trochę", natomiast $10 \%$ stwierdziło, że leczenie nie miało pozytywnego wpływu na postrzeganie dziecka $\mathrm{w}$ grupie rówieśniczej. Znalazło to częściowe potwierdzenie w ocenie poszczególnych obszarów kwestionariusza zdrowotnego KIDSCREEN-52. Najwyższe średnie wartości standaryzowanej skali wykazano dla obszarów: nastroje i emocje 
$(84,55 \pm 12,73)$, relacje z rodzicami i dom $(81,83 \pm 10,88)$ oraz akceptacja społeczna $(89,86 \pm 12,86)$. Wyniki świadczyły o wysokim poziomie jakości życia w tych obszarach. Najniższe średnie wartości, świadczące o niskim poziomie jakości życia prezentowały obszary: zasoby finansowe $(70,14 \pm 17,44)$, wsparcie społeczne i koledzy $(65,51 \pm$ $16,60)$ oraz środowisko szkolne $(67,34 \pm 15,78)$. Wyniki pozostałych obszarów przedstawiono w Tabeli 1.

Dokonano również analizy zależności między poszczególnymi obszarami oceny leczenia/satysfakcji rodziców a obszarami jakości życia dzieci. Istotne statystycznie zależności zaobserwowano dla sześciu par zmiennych. Stwierdzono, że im wyższa jakość obszaru samopoczucia fizycznego i zdrowia, tym mniejsza potrzeba przygotowania psychicznego dziecka do wizyt w szpitalu w związku z leczeniem. Im wyższa jakość obszaru wsparcia społecznego i kolegów, tym mniejsze utrudnienie wynikające $\mathrm{z}$ wizyt na oddziale szpitalnym związanych z leczeniem również mniejsza potrzeba przygotowania psychicznego dziecka do wizyt w szpitalu. Wyższy poziom zasobów finansowych związany był istotnie z mniejszym wzrostem samooceny dziecka w wyniku stosowanego leczenia oraz mniejszym wpływem leczenia na bardziej pozytywne postrzeganiem dziecka w grupie rówieśniczej. 
Tabela 1.Statystyki opisowe poszczególnych obszarów kwestionariusza KIDSCREEN-52 $\mathrm{w}$ wersji dla rodziców $(\mathrm{N}=69)$.

\begin{tabular}{|l|c|c|c|c|c|c|c|}
\hline \multicolumn{1}{|c|}{ Obszar } & $\begin{array}{c}\text { Wska } \\
\text { źnik }\end{array}$ & $\begin{array}{c}\text { Śred- } \\
\text { nia }\end{array}$ & $\begin{array}{c}\text { Odchy- } \\
\text { lenie } \\
\text { stan- } \\
\text { dar- } \\
\text { dowe }\end{array}$ & $\begin{array}{c}\text { Media } \\
\text { na }\end{array}$ & $\begin{array}{c}\text { Mini- } \\
\text { mum }\end{array}$ & $\begin{array}{c}\text { Maksi- } \\
\text { mum }\end{array}$ & Zakres \\
\hline $\begin{array}{l}\text { Samopo- } \\
\text { czucie fi- } \\
\text { zyczne } \\
\text { i zdrowie }\end{array}$ & W1 & 71,88 & 13,09 & 76,00 & 32,00 & 96,00 & 64,00 \\
\hline $\begin{array}{l}\text { Samopo- } \\
\text { czucie psy- } \\
\text { chiczne }\end{array}$ & W2 & 74,73 & 11,54 & 76,67 & 40,00 & 100,00 & 60,00 \\
\hline $\begin{array}{l}\text { Nastroje } \\
\text { i emocje }\end{array}$ & W3 & 84,55 & 12,73 & 85,71 & 22,86 & 100,00 & 77,14 \\
\hline $\begin{array}{l}\text { Obraz wła- } \\
\text { snej osoby }\end{array}$ & W4 & 77,62 & 12,37 & 80,00 & 44,00 & 100,00 & 56,00 \\
\hline $\begin{array}{l}\text { Niezależ- } \\
\text { ność }\end{array}$ & W5 & 70,72 & 12,53 & 68,00 & 52,00 & 100,00 & 48,00 \\
\hline $\begin{array}{l}\text { Relacje } \\
\text { z rodzicami } \\
\text { i dom }\end{array}$ & W6 & 81,83 & 10,88 & 83,33 & 53,33 & 96,67 & 43,33 \\
\hline $\begin{array}{l}\text { Zasoby fi- } \\
\text { nansowe }\end{array}$ & W7 & 70,14 & 17,44 & 66,67 & 20,00 & 100,00 & 80,00 \\
\hline $\begin{array}{l}\text { Wsparcie } \\
\text { społeczne } \\
\text { i koledzy }\end{array}$ & W8 & 65,51 & 16,60 & 63,33 & 20,00 & 100,00 & 80,00 \\
\hline $\begin{array}{l}\text { Środowisko } \\
\text { szkolne }\end{array}$ & W9 & 67,34 & 15,78 & 70,00 & 26,67 & 100,00 & 73,33 \\
\hline $\begin{array}{l}\text { Akceptacja } \\
\text { społeczna }\end{array}$ & W10 & 89,86 & 12,86 & 93,33 & 40,00 & 100,00 & 60,00 \\
\hline
\end{tabular}


Stwierdzono, również, że im wyższa jakość obszaru środowiska szkolnego, tym mniejszy wpływ leczenia na bardziej pozytywne postrzeganie dziecka w grupie rówieśniczej. Potwierdziło to wypowiedzi, rodziców w kwestionariuszu, w którym 17\% rodziców oceniło jakość życia dziecka w trakcie leczenia jako doskonałą, 55\% jako bardzo dobrą, 26\% dobrze. 1\% udzielił odpowiedzi „tak sobie”.

Dokonano analizy korelacyjnej poszczególnych obszarów oceny leczenia i osiągniętego przyrostu dziecka. Analizy wykazały, że osiągnięty przyrost wysokości dziecka korelował ze zgodnością efektu leczenia z oczekiwaniami rodziców. Współczynnik Rs =-0,458 przy poziomie $\mathrm{p}=0,000$ oznaczał, że im większy przyrost, efekt leczenia był bardziej zgodny z oczekiwaniami rodziców (Rycina 1).

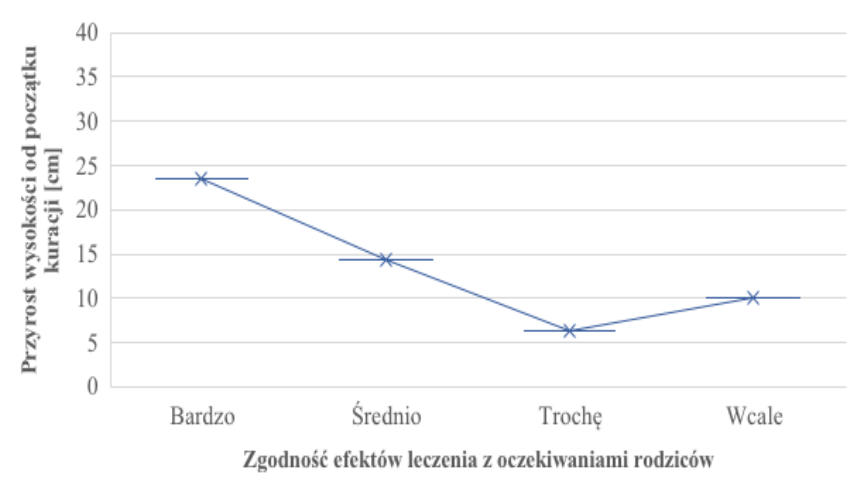

Rycina 1. Graficzne porównanie rozłożenia średnich arytmetycznych przyrostu wysokości (od początku kuracji) zgodności efektów leczenia z oczekiwaniami rodziców ( $\mathrm{N}=67)$.

\section{Dyskusja}

W Polsce każdego roku zgłasza się do lekarza endokrynologa ok 200 dzieci z powodu niskorosłości. Osoby niskiego wzrostu są obecne wśród nas. Często niskorosłość związana jest z uwarunkowaniami 
rodzinnymi i genetycznymi. Tylko 2\%-8\% ma niedobór wzrostu, który wymaga leczenia hormonem. Terapia hormonem wzrostu jest promowana na świecie. Postęp medycyny pozwala na osiągnięcie wzrostu zadowalającego samo dziecko i rodziców. Dlatego rodzice chcą aby ich dziecko było zakwalifikowane do leczenia[19].

Przeprowadzone badania dotyczące satysfakcji rodziców z leczenia SNP, zakładają że ocena poziomu satysfakcji rodziców z leczenia możliwa jest przez ocenę jakości życia dzieci z niskorosłością w trakcie leczenia. Rodzic, który wysoko ocenia jakość życia dziecka w trakcie kuracji hormonem, pozytywnie ocenia całą kurację jest usatysfakcjonowany z całego programu terapii.

Buczyńska-Górna w swojej Rozprawie doktorskiej badała „Jakość życia dzieci i młodzieży z somatotropinowa niedoczynnością przysadki przed i w trakcie leczenia ludzkim rekombinowanym hormonem wzrostu". Praca opisuje wiele aspektów życia dziecka z niskorosłością i jego całej rodziny. Autorka mówi o wpływie niskorosłości na funkcjonowanie rodziny dziecka[20].

Quitmann opisuje w artykule „Quality of life of short-statured children born small for gestational age or idiopathic growth hormone", obawy, stres u rodziców związany z leczeniem dzieci. Autorka opisuje odczucia rodziców co do terapii, przebiegu i satysfakcji z efektu leczenia [11].

Badania własne wykazały, że uzyskanie zadowalającej odpowiedzi wzrostowej jest głównym celem terapii hormonem u dzieci z SNP. Rodzice czują się usatysfakcjonowani z efektów wzrostowych. Jak pisze Buczyńska Górna, pozytywne nastawienie pacjenta i rodziny do prowadzonej terapii jest jednym z warunków do uzyskania dobrych rezultatów z leczenia"[20]. Stwarza to konieczność do wprowadzenia parametrów, które oceniają cały wpływ choroby, zastosowanej terapii na życie i funkcjonowanie całej rodziny. Pomimo obaw, związanych z długotrwałym leczeniem, obowiązujących obostrzeniach - wizyty 
i badania kontrolne, codzienne iniekcje i konieczność prawidłowego przechowywania lek, rodzice za wszelką cenę chcą aby ich dziecko było objęte programem leczenia. Pozwala to na uspokojenie sumienia i że zrobiło się wszystko aby ułatwić start dziecka w dorosłym życiu. Julia Quitmann w badaniach analizując dane rodziców pisze, że odczuwają oni niepokój związany z leczeniem ich dzieci, mówi o rodzicielskim poczuciem smutku z powodu poczucia winy i frustracji podczas podawania zastrzyków, co wpływa na satysfakcję i cały proces leczenia. Autorzy podkreślają, że rodzice i pacjenci podejmując decyzje za i przeciw leczeniu GH muszą posiadać pełną wiedzę na temat leczenia[11].

Kolejnym aspektem poddanym analizie była ocena jakości życia dziecka leczonego hormonem. W badaniu rodzice wysoko oceniają jakość życia dziecka w trakcie terapii. Oceniono zależność między satysfakcja rodziców z leczenia a jakością życia leczonego dziecka. 17\% rodziców oceniło jakość życia w trakcie leczenia jako doskonałą, 55\% jako bardzo dobrą, 26\% dobrze. Buczyńska -Górna w swoich badaniach wykazuje poprawę w zakresie aktywności fizycznej, samooceny, funkcjonowania dzieci w szkole. A także pozytywnego oddziaływania terapii hormonem na całą rodzinę, podnosi jakość życia. [9] Leczenie rekombinowanym hormonem wzrostu jest nie tylko promującym wzrastanie ale działając wielokierunkowo daje możliwość dużej poprawy jakości życia, wywierając korzystny wpływ na funkcjonowanie psychospołeczne dziecka i rodziny[21].

Satysfakcja rodziców z leczenia hormonem wzrostu jest ściśle powiązana z efektami leczenia i poprawą jakości życia ich dzieci. Znalazło to potwierdzenie $\mathrm{w}$ przeprowadzonych badaniach ale również $\mathrm{w}$ literaturze. Esther Leiberman i wsp. w swej pracy ocenili satysfakcję z leczenia rekombinowanym hormonem wzrostu wysoko. Umiejętność radzenia sobie z przewlekłą chorobom, która wymaga długiego leczenia wpływa na jakość życia dzieci i ich rodziców. W badaniach tych autorów stwierdzono, że mimo iż terapia hormonem stanowi duże 
obciążenie dla pacjentów i rodziców, wszyscy „radzili sobie” i wyrażali zadowolenie z leczenia. Zdolność radzenia sobie i satysfakcja z leczenia służą jako wskaźnik jakości leczenia. Badacze udowadniają, że pacjenci i rodzice traktują terapię jako inwestycję, którą są gotowi wykonać aby zwiększyć swój wzrost. W ich badaniach długość leczenia nie wpłynęła na wynik radzenia sobie i satysfakcji z leczenia. Dzieci z zaburzeniami wzrastania cierpią na niepełnosprawność społeczną i psychiczną nie mniej korzyści wynikające $\mathrm{z}$ leczenia hormonem wnoszą w ich życie wiele pozytywnych zmian[22].

\section{Wnioski}

1. Rodzice dzieci z somatotropinową niedoczynnością przysadki są usatysfakcjonowani z leczenia rekombinowanym hormonem wzrostu i oceniają kuracje pozytywnie. Z badań wynika, że wysoko oceniają jakość życia swoich dzieci w trakcie terapii hormonem wzrostu.

2. Zależność między oceną leczenia hormonem przez rodziców a oceną jakości życia dzieci z somatotropinową niedoczynnością przysadki potwierdziła się. Lepsze zdrowie i samopoczucie dziecka skutkuje mniejszymi problemami w dalszym leczeniu.

3. Satysfakcja rodziców z leczenia rekombinowanym hormonem wzrostu jest zależna od czasu trwania kuracji i osiągniętych rezultatów wzrostowych. Efekt leczenia jest zgodny z oczekiwaniami rodziców.

\section{Zalecenia dla praktyki pielęgniarskiej}

Świadomość, że niskorosłość dziecka nie jest tylko jego problemem fizycznym, ale również emocjonalnym i społecznym pozwala pielęgniarce zaplanować i dopasować swoje postępowanie do etapu leczenia na jakim dziecko się znajduje. Biorąc pod uwagę długotrwałość terapii i jej uciążliwość dla pacjenta, pielęgniarka musi nawiązać 
odpowiednie relacje z chorym i jego rodzicami w celu zapewnienia im poczucia bezpieczeństwa jednocześnie zapewniając o słuszności podjętej decyzji leczenia.

W swoim działaniu pielęgniarka musi pamiętać, że wynik terapii w dużej mierze zależy od zaangażowania rodziców chorego dziecka, którzy sukces mierzą wielkością wzrostu i poprawą jakości życia swoich dzieci. Należy tak zaplanować swoje działania edukacyjne, aby umiejętnie wdrożyć rodziców w długotrwały proces leczenia i problemy z tego wynikające.

\section{Bibliografia/Bibliography:}

1. Beń-Skowronek I. Leczenie niskorosłości u dzieci. Forum pediatrii praktycznej. 2016; 11.

2. Pyrżak B. Endokrynologia wieku rozwojowego. PZWL 2019.

3. Radzikowski A. Pediatria Podręcznik dla studentów pielęgniarstwa. Wydawnictwo MediPage, Warszawa 2008.

4. Romer E. Dziecko niskorosłe. Pediatria po dyplomie, Wydanie Specjalne, Wrzesień 2008.

5. Zbukiewicz-Kucharska A. Wpływ wybranych czynników na skuteczność leczenia GH u dzieci z somatotropinową niedoczynnością przysadki. Endokrynologia Pediatryczna 2014;13,4(49).

6. Bednarczuk T. ITEM Publishing Podstawy endokrynologii. Warszawa 2017.

7. Oświęcimska J. Niedobór hormonu wzrostu u dzieci młodych i dorosłych. Postępy Hig med. Dosw,2016;70:928-937.

8. Pilch T. Zasady badań pedagogicznych, Wydawnictwo Żak, Warszawa 2010:46,71. 
9. Bednarczuk T. Niedoczynność przysadki 2014 https://www.mp.pl/pacjent/endokrynologia/choroby/78201, niedoczynnosc-przysadki, (111118) .

10. Melissa D. Problemy kliniczne w diagnostyce dziecka niskorosłego. 2015. https;//www.mp.pl./pediatria/2014/43:321-327.

11. Quitmann J. Quality oj fife od short-statured children born small for gestational age or idiopathic growth hormone deficiency within 1 year of growth hormone treatment. Orginal Research 2019.

12. Bielecka-Jasiocha J. Psychospołeczne funkcjonowanie dzieci niskorosłych, Endokrynologia Pediatryczna, 2008;7,1(22).

13. Borek E. Gorsze wzrastanie dziecka- dylematy terapeutyczne. Medical Tribune 2015.

14. Buczyńska-Górna M. Zastosowanie Kwestionariusza Samopoczucia Dziecka Leczonego Hormonem Wzrostu do badania dzieci z somatotropinową niedoczynnością przysadki podczas terapii rekombinowanym ludzkim hormonem wzrostu. Endokrynologia Pediatryczna $2012 ; 11,4(41)$.

15. Krukowska-Andrzejczyk B. Czy terapia rekombinowany hormonem wzrostu ma wpływ na poprawę jakości życia dzieci z idiopatycznie niskim wzrostem. Endokrynologia Pediatryczna 2010;10,3(36).

16. Oleś M. Subiektywna jakość życia, poczucie własnej wartości i postrzegane wsparcie społeczne u nastolatków z zaburzeniami endokrynnymi. Endokrynologia Pediatryczna 2014;13:35-48.

17. Hilczer M. Wskazania do leczenia hormonem wzrostu u dzieci i dorosłych. Przegląd Pediatryczny 2004; 34,3/4.

18. Lewiński A. Ogólnopolski Program Leczenia Ciężkiego Niedoboru Hormonu Wzrostu u Osób Dorosłych oraz u Młodzieży po Zakończeniu Terapii Promującej Wzrastanie. Endokrynologia Polska. 2018;69,5. 
19. Biczysko-Mokosa A. Ocena wybranych parametrów i metod przewidywania wzrostu końcowego u pacjentów z trwałym i przejściowym niedoborem hormonu wzrostu. Endokrynologia Pediatryczna 2012;11,3(40).

20. Buczyńska-Górna M. Jakość życia u dzieci i młodzieży z somatotropinową niedoczynnością przysadki przed i w trakcie leczenia ludzki rekombinowanym hormonem wzrostu. Rozprawa doktorska napisana pod kierunkiem dr hab.n.med. Andrzeja Kędzi 2009, Uniwersytet Medyczny im. Karola Marcinkowskiego w Poznaniu.

21. Barstow C., Evaluation of short and tall stature in children, https://www.mp.pl./endokrynologia/wytyczne 173471, 10.11.2017.

22. Leiberman E. Coping and Satisfaction with Growth Hormone Teratment among Short-Stature Children. Hormone Research in Peadiatrics 40(4)128-135, 2002. 